\title{
Geochemical and Petrophysical Characterization of the Bakken Shale in Mountrail County, North Dakota
}

\section{*Chioma Onwumelu}

Co-authors: Adedoyin Adeyilola \& Francis Nwachukwu

Advisor: Stephan Nordeng *chioma.Onwumelu@und.edu

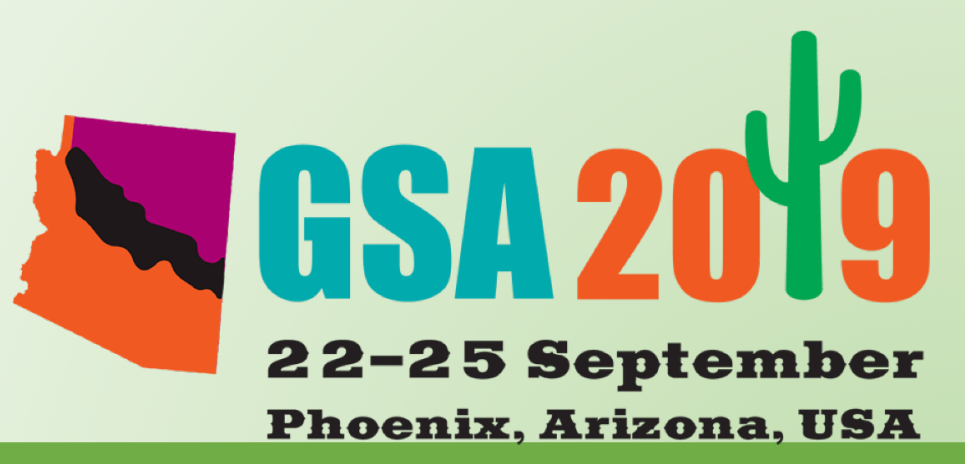


- Introduction

- Motivation

- Study Area

- Methods

- Source Rock Analysis

- Scanning Electron Microscope

- X-ray Diffraction

- Nuclear Magnetic Resonance

- Results

- Conclusions 


\section{Motivation}

- Bakken Formation is one of the most prolific tight plays in the Williston Basin. However, due to its heterogeneity and very low porosity and permeability, the Bakken recovery factors remain small (5\%-10\%).

- The Bakken Petroleum System consist of source rocks that have been buried to depths and temperatures that have generated significant volumes of oil (million barrels of 42 API gravity)

- Connected matrix related pores alongside a fracture form flow pathway network 


\section{Study Area}

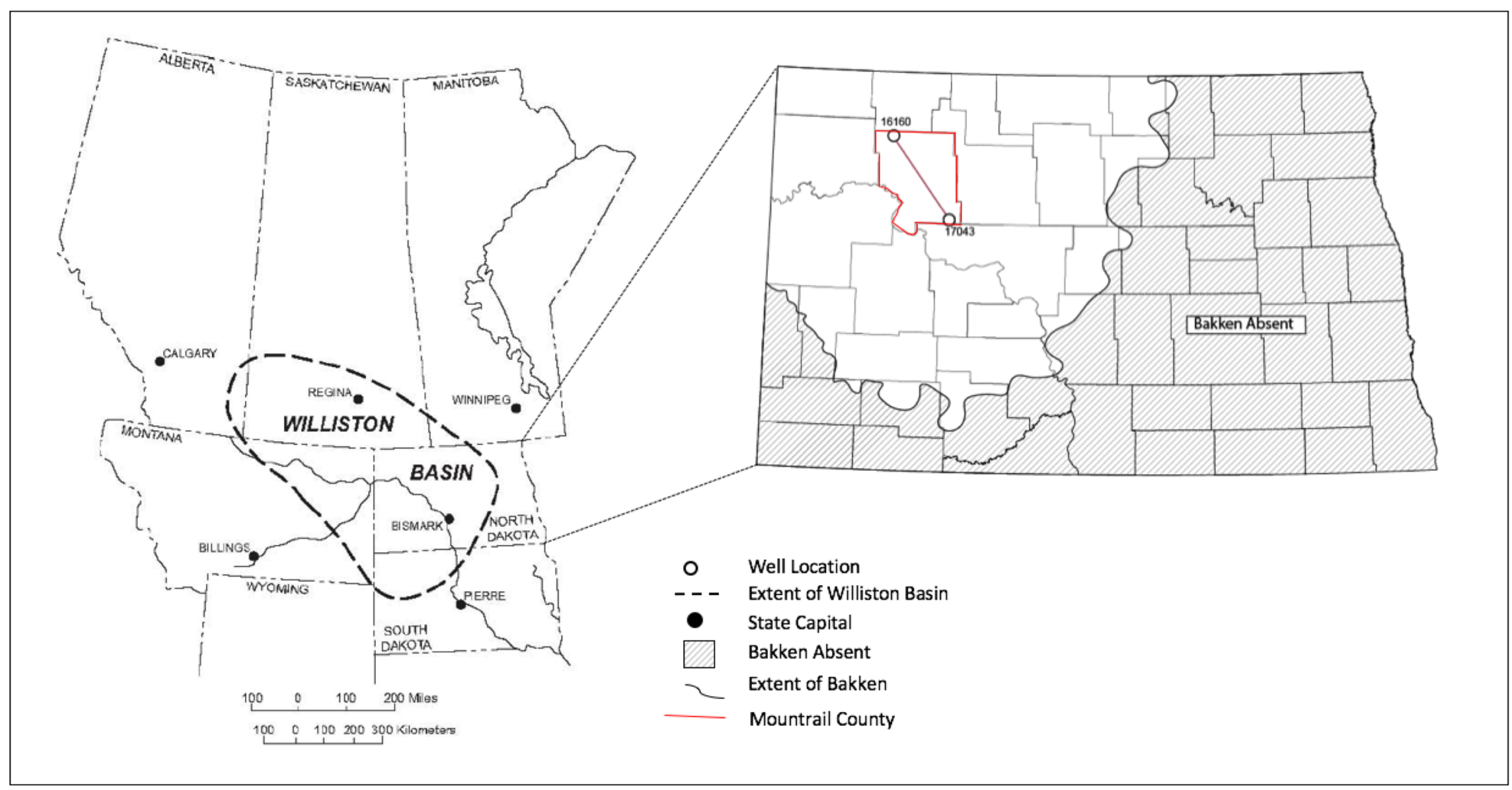

2 wells Mountrail County

\begin{tabular}{|c|c|}
\hline NDIC No & $\begin{array}{c}\text { Depth to Bakken } \\
(\mathrm{ft})\end{array}$ \\
\hline 17043 & 9072 \\
\hline 16160 & 9511 \\
\hline
\end{tabular}




\section{Methods}

- Source Rock Potential and Maturity

- Scanning Electron Microscope Analysis

- X-ray Diffraction

- Nuclear Magnetic Resonance Analysis

- Scan sample

- Evacuate air

- Saturate sample (Nacl brine) 



\section{Introduction

\section{Results (XRD)}

17043-Immature

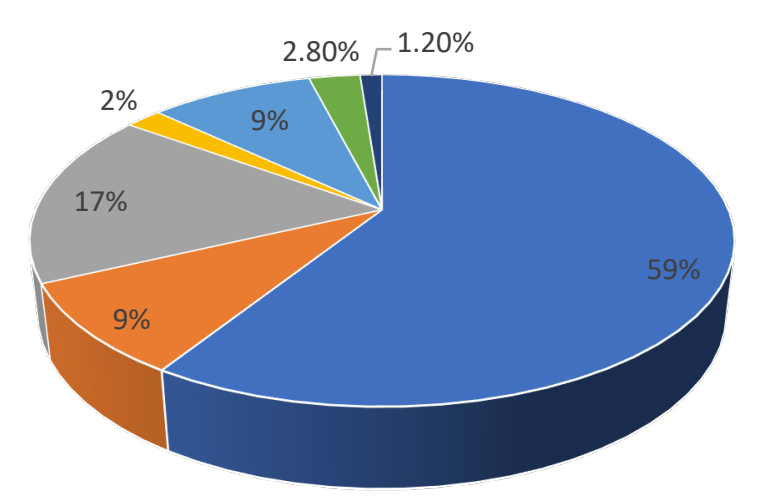

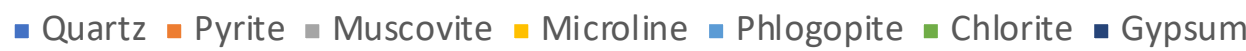

16160-Mature

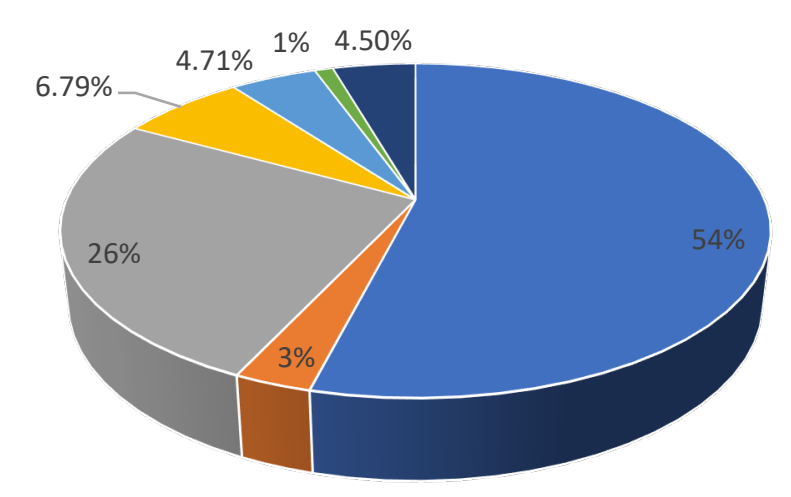

- Quartz - Pyrite - Aluminoceladonite $\|$ Sanidine $\|$ Chlorite $\|$ Apatite - Illite

- Immature well has higher content of pyrite than the mature sample

- Mature sample has high content of clay mineral than the immature sample 


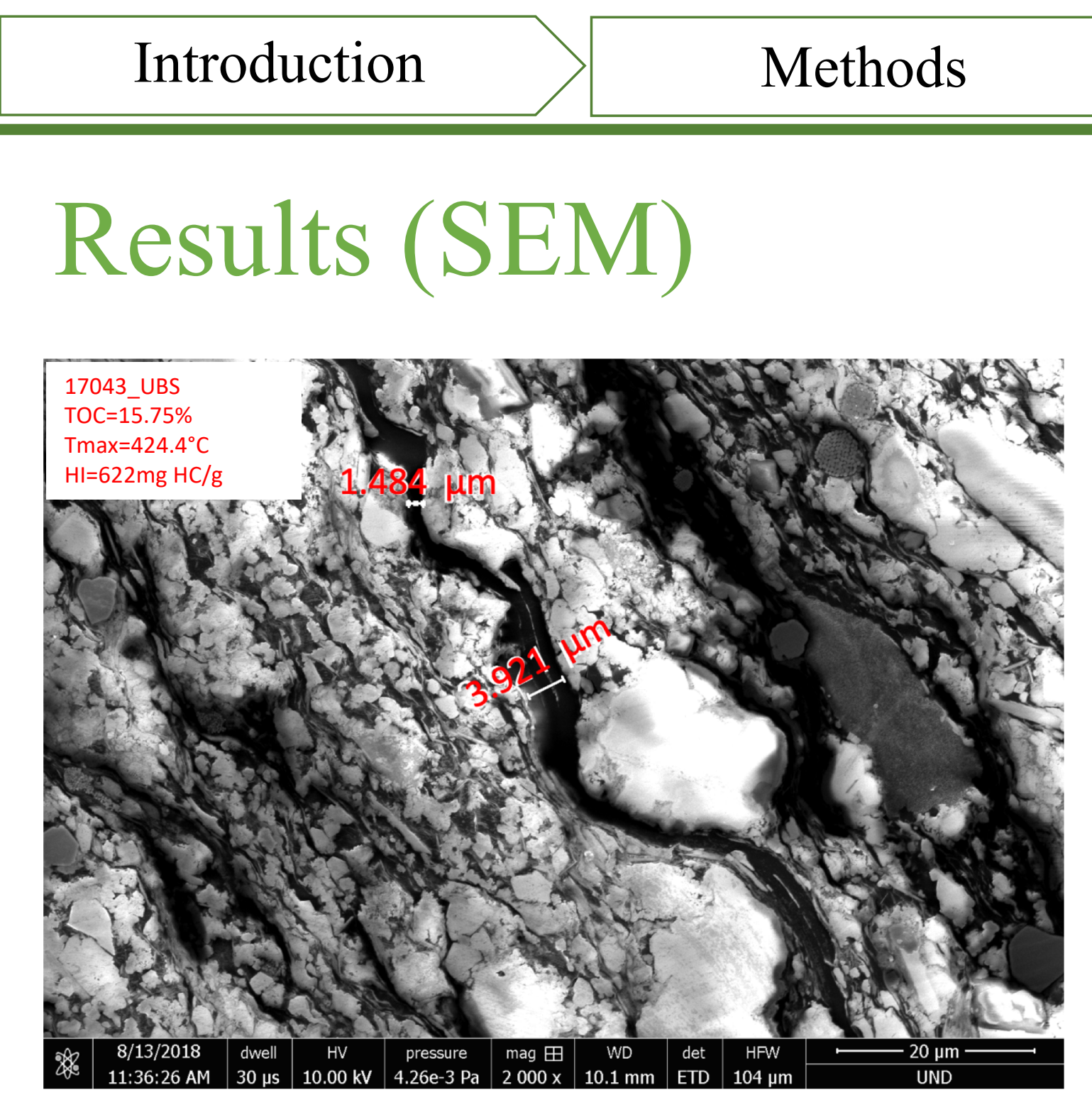

Size of pores within the immature sample

\section{Results}

\section{Conclusions}

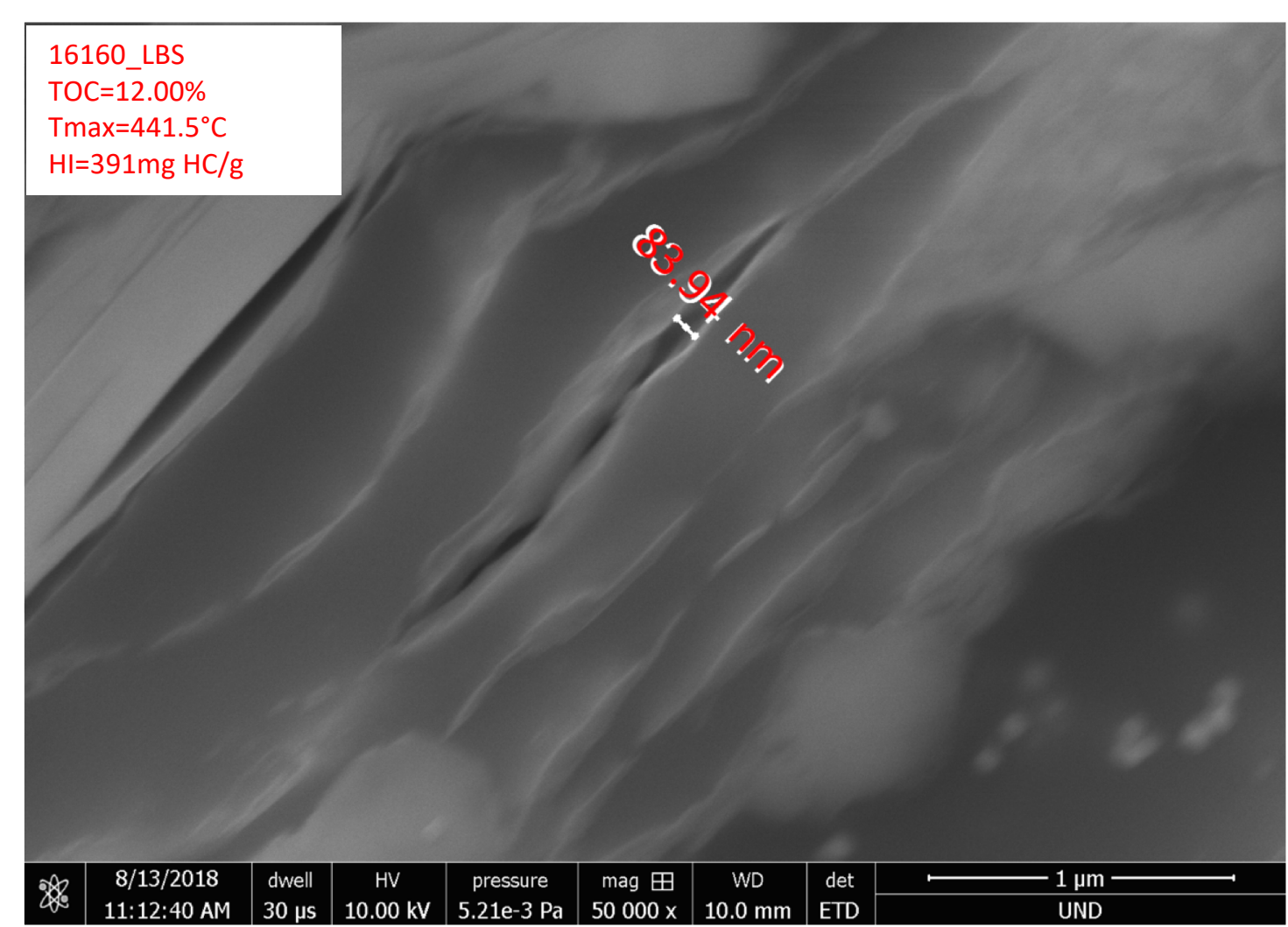

Size of pores within the mature sample 


\section{Conclusions}

- Excellent source rock (12.00 to $15.75 \mathrm{wt} \%)$.

- Immature sample with highest TOC content (15.75 wt.\%) has more organic porosity.

- Three pore types are found within Bakken Shales (mineral matrix, organic matter and fracture pores)

- The pore types were controlled by properties individual mineral within the samples

- Bakken source rocks are comprised of mainly nanometer to micrometer pore sizes. 


\section{Future Work}

- Analyze more wells in the Williston Basin

- NMR logs 


\section{Acknowledgement}

- Special thanks to North Dakota Geological Survey (NDGS) and Energy \& Environmental Research Center (EERC)
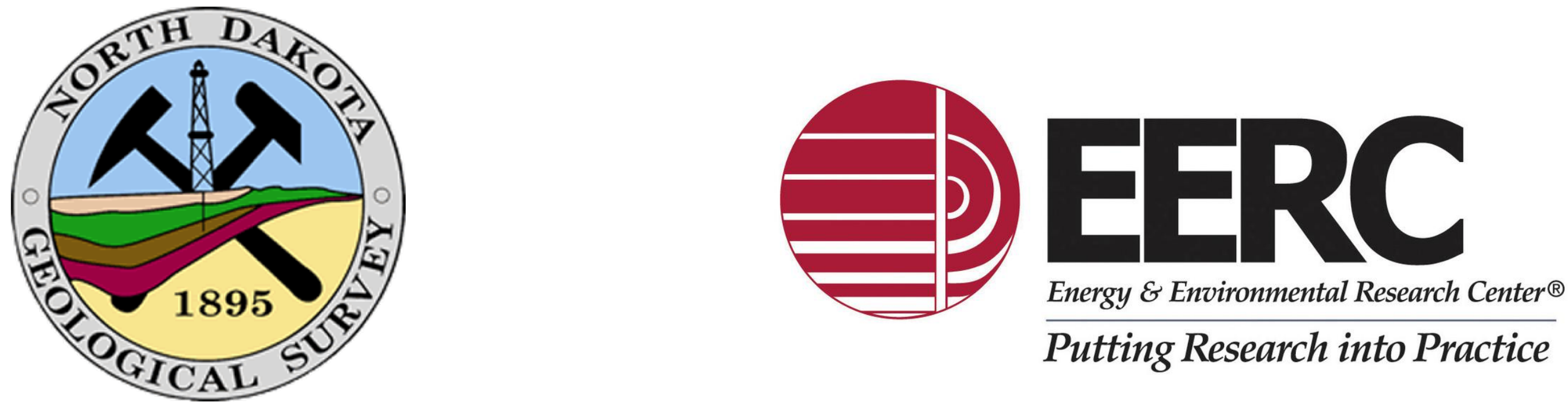


\section{Questions?}


1. Brownstein, K. R., \& Tarr, C. E. (1979). Importance of classical diffusion in NMR studies of water in biological cells. Physical review A, $19(6), 2446$.

2. Clarkson, C. R., Solano, N., Bustin, R. M., Bustin, A. M. M., Chalmers, G. R. L., He, L., ... \& Blach, T. P. (2013). Pore structure characterization of North American shale gas reservoirs using USANS/SANS, gas adsorption, and mercury intrusion. Fuel, 103, 606-616.

3. Dunn, K. J., Bergman, D. J., \& LaTorraca, G. A. (Eds.). (2002). Nuclear magnetic resonance: Petrophysical and logging applications (Vol. 32). Elsevier.

4. Grunewald, E., \& Knight, R. (2009). A laboratory study of NMR relaxation times and pore coupling in heterogeneous media. Geophysics, 74(6), E215-E221.

5. Green, D. P., \& Veselinovic, D. (2010). Analysis of unconventional reservoirs using new and existing NMR Methods. GeoCanada, Calgary, Canada.

6. Jin, H., \& Sonnenberg, S. A. (2014). Characterization for source-rock potential of the Bakken Shales in the Williston basin, North Dakota and South Montana. In $A A P G$ Annual Convention and Exhibition (p. 37). Pittsburgh, PA: American Association of Petroleum Geologists.

7. LeFever, J. A., Martiniuk, C. D., Dancsok, E. F., \& Mahnic, P. A. (1991). Petroleum potential of the middle member, Bakken Formation, Williston Basin. Williston Basin Symposium.

8. Loucks, R. G., Reed, R. M., Ruppel, S. C., \& Hammes, U. (2012). Spectrum of pore types and networks in mudrocks and a descriptive classification for matrix-related mudrock pores. AAPG bulletin, 96(6), 1071-1098.

9. Peters, K. E., \& Cassa, M. R. (1994). Applied source rock geochemistry: Chapter 5: Part II. Essential elements.

10. Prammer, M. G., Dudley, J. H., Masak, P., Goodman, G. D., Morys, M., Jones, D. A., ... \& Smaardyk, J. E. (2004). U.S. Patent No. 6,825,659. Washington, DC: U.S. Patent and Trademark Office.

11. Ross, D. J., \& Bustin, R. M. (2009). The importance of shale composition and pore structure upon gas storage potential of shale gas reservoirs. Marine and Petroleum Geology, 26(6), 916-927.

12. Sandberg, C. A., \& Hammond, C. R. (1958). Devonian system in Williston Basin and central Montana. AAPG Bulletin, 42(10), $2293-2334$.

13. Smith, M. G., \& Bustin, R. M. (1995). Sedimentology of the Late Devonian and Early Mississippian Bakken Formation, Williston Basin. Williston Basin Symposium.

14. Thrasher, L. C. (1985). Macrofossils and biostratigraphy of the Bakken Formation (Devonian and Mississippian) in western North Dakota.

15. Webster, R. L. (1984). Petroleum source rocks and stratigraphy of Bakken Formation in North Dakota. AAPG Bulletin, 68(7), 953-953.

16. Wignall, P. B. (1991). Model for transgressive black shales?. Geology, 19(2), 167-170.

17. Wignall, P. B., \& Maynard, J. R. (1993). The sequence stratigraphy of transgressive black shales. AAPG Stud. Geol, 37, 35-47.

18. Xu, J., \& Sonnenberg, S. A. (2017, September). An SEM Study of Porosity in the Organic-rich Lower Bakken Member and Pronghorn Member, Bakken Formation, Williston Basin. In Unconventional Resources Technology Conference, Austin, Texas, 24-26 July 2017 (pp. 3213-3225). Society of Exploration Geophysicists, American Association of Petroleum Geologists, Society of Petroleum Engineers. 